\title{
Birdshot chorioretinopathy: clinical characteristics and evolution*
}

\author{
HILDE A PRIEM'2 AND JENDO A OOSTERHUIS ${ }^{2}$ \\ From the 'Eye Clinic, University of Gent, Belgium, and the ${ }^{2}$ Eye Clinic, University of Leiden, The Netherlands
}

SUMmaRY During the period 1980-6102 patients from 14 European eye clinics were diagnosed as having birdshot chorioretinopathy (BSCR). All were Caucasian, and the series consisted of $47 \mathrm{men}$ and 55 women, with a mean age of 52.5 years. The major findings in this rare disorder concern the ocular fundus. Most marked are the patterned distribution of depigmented spots without hyperpigmentation, radiation from the optic disc in association with vitritis, retinal vasculopathy with frequent cystoid macular oedema, and involvement of the optic nerve head. The distribution and appearance of the lesions suggest that they are related to the major choroidal veins. Complications of the disease were epiretinal membranes, retinal neovascularisation, recurrent vitreous haemorrhage, subretinal neovascular membranes occurring both in the juxtapapillary and macular regions, and optic atrophy. The medical history was not contributary. HLA testing showed very strong disease association with HLA A29 (95.8\%). The evidence suggests that it is a single disease entity rather than a group of disorders because of the remarkable similarity in the ophthalmological appearance and the clinical course, combined with the exceptionally high association with HLA A29.

In 1980 a rare ocular disease was described by Ryan and Maumenee.' In the absence of a known aetiology, they chose the descriptive name 'birdshot retinochoroidopathy' inspired by the unusual picture, which showed multiple small, cream coloured lesions, scattered mainly around the optic disc and radiating towards the equator, without hyperpigmentation at the level of the retinal pigment epithelium. Because of the presence of vitritis, retinal vasculitis, and cystoid macular oedema they likened the disease to pars planitis, but emphasised the absence of snowbanking over the pars plana.

Other descriptive names have been used for this

*This paper is the result of a collaboration by the following members of the European Fluorescein Angiography Club: P Amalric (Albi, France); M Spitznas (Bonn, FRG); C Orsini Dupont (Caen, France); G Coscas, A Gaudric, G Soubrane (Créteil, France); J J de Laey, H A Priem (Gent, Belgium); J Hooymans, Z Timmerman (Groningen, The Netherlands); J A Oosterhuis, A H Renger-van Dijk (Leiden, The Netherlands); A Leys, B Snyers (LeuvenLouvain, Belgium); A Bird, R Blach, Z Gregor, A M Hamilton, D Sharp, J Shilling (London, England); A F Deutman (Nijmegen, The Netherlands); J A Bernard, G Quentel (Paris, France); G S Baarsma, P T V M de Jong, B C P Polak (Rotterdam, The Netherlands).

Correspondence to $\mathrm{Dr} \mathrm{H}$ A Priem, Dienst Oogheelkunde, Academisch Ziekenhuis, De Pintelaan 185, 9000 Gent, Belgium.

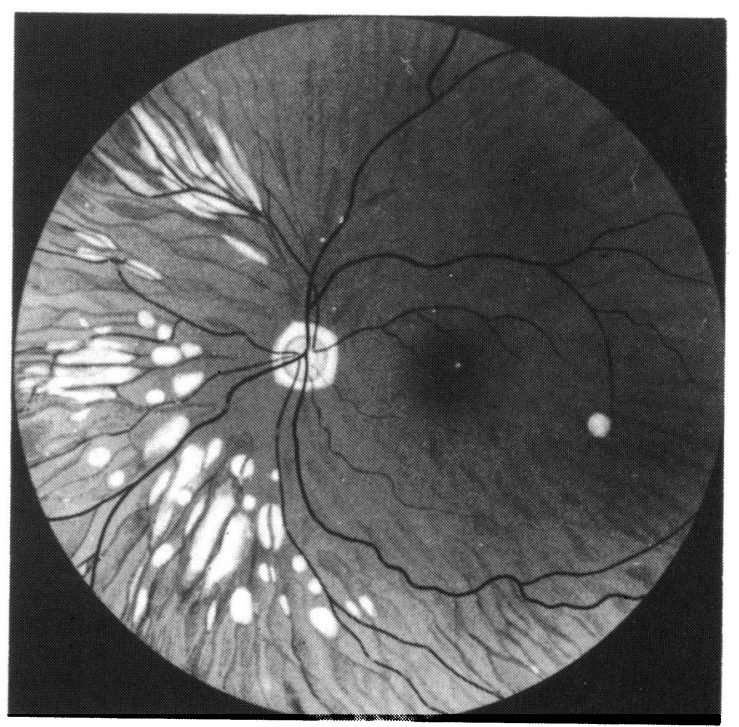

Fig. 1 Patient of Franceschetti and Babel ${ }^{5}$ with systemic sarcoidosis. White flecks predominantly in nasal periphery and round optic disc with radial pattern and tendency to form lines towards periphery. (By permission of the Fondation Professor A Franceschetti.) 
entity, such as 'vitiliginous chorioretinitis' by Gass, ${ }^{2}$ who stressed the similarity of the fundus patches to cutaneous vitiligo, 'salmon-patch choroidopathy' by Aaberg, ${ }^{3}$ and 'choriorétinopathie en grains de riz' by Amalric and $\mathrm{Cuq}^{+}{ }^{+}$who saw a similarity to the rice grain pattern.

Probably the first description of birdshot chorioretinopathy (BSCR) in the early literature occurred in 1949 in a case report by Franceschetti and Babel. ${ }^{5}$ They described a 63-year-old woman with a condition they named 'choriorétinopathie en taches de bougie' (candlewax spots), who had systemic features of sarcoidosis. On ocular examination she had minimal involvement of the anterior segment with only minute keratic precipitates (KP) but had dense vitreous opacity. The authors described a pale optic disc, very narrow retinal vessels, and multiple white 'retinal and chorioretinal' spots, and stressed the absence of pigmentation of the spots (Fig. 1). Later they saw areas of choroidal atrophy appear in the inferonasal quadrant. All these features are characteristic of BSCR.

Other authors have highlighted special characteristics of BSCR such as distinctive electrophysiological abnormalities ${ }^{6}$ its association with the HLA A29 gene, ${ }^{7}$ and the occurrence of complications such as subretinal neovascular membranes ${ }^{89}$ and optic atrophy. ${ }^{12}$ The association with a rhegmatogenous retinal detachment has also been reported. ${ }^{161011}$ More case reports followed ${ }^{12-17}$ dealing with small numbers of patients only, giving the overall impression that BSCR is a rare disease.

In this study we analyse in a large series of patients the entity known as birdshot chorioretinopathy (BSCR) as defined by the accepted clinical picture. In particular, we sought to determine whether or not this is a single clinical entity or simply a collection of exotic cases with similar appearance.

\section{Subjects and methods}

The patients were collected from 14 ophthalmological departments in five European countries. The minimum criteria used for patient selection were based on the clinical manifestations as described by Ryan and Maumenee.' Each patient was required to have the typical cream coloured birdshot spots with a symmetrical appearance in both eyes (if asymmetrical, then one eye should at least be very characteristic of BSCR in number, size, and distribution of the lesions), together with one of the following features: evidence of retinal vasculopathy, evidence of disc oedema or optic atrophy, or presence of vitreous cells.

The patients consisted of 47 men aged 23-79 years (average 50.7 years) and 55 women aged $32-74$ years (average 54.4 years). All were Caucasian. They were examined both clinically and by colour photography and fluorescein angiography (Table 1). The clinical files and the photographic documentation were studied by one of us (HAP).

The first set of data included the general history, with specific reference to skin disease, allergy, and hearing loss; and the ocular history, which covered previous eye disease, surgery, and family history. The second set of data concerned the clinical examination, including visual acuity, findings on slit-lamp examination, tonometry, and ophthalmoscopy. The third described the fluorescein angiographic findings. The fourth dealt with additional investigations such as colour vision tests, perimetry, dark adaptation, electro-oculogram (EOG), electroretinogram (ERG), visually evoked potentials (VEP), and HLA typing. Finally, long term behaviour and the influence of treatment were assessed.

\section{Table 1 Clinical and functional investigations}

\begin{tabular}{ll}
\hline & $\begin{array}{l}\text { Number of BSCR patients } \\
\text { involved }\end{array}$ \\
\hline Total number in study & 102 \\
Fundus pictures & 102 \\
Fluorescein angiography & 102 \\
Medical history & 71 \\
Ocular history & 79 \\
Slit-lamp & 68 \\
Tonometry & 60 \\
Visual acuity & 94 \\
Colour vision tests & 31 \\
Perimetry & 43 \\
Dark adaptation tests & 24 \\
EOG and ERG & 42 \\
VEP & 30 \\
HLA typing & 48 (in 5 patients A29 only) \\
\hline
\end{tabular}

Table 2 Medical history in 71 BSCR patients

\begin{tabular}{ll}
\hline & No. of patients \\
\hline Arterial hypertension & 16 \\
Cardiac disease & 5 \\
Cerebrovascular accident & 2 \\
Rheumatic disease, arthritis & 6 \\
Low backache & 2 \\
Gout & 1 \\
Allergy (penicillin, fluorescein) & 6 \\
Eczema, psoriasis & 4 \\
Hirsutism & 1 \\
Vitiligo (only in summer season) & 1 \\
Hearing loss & 3 \\
Menière's disease & 1 \\
Migraine & 1 \\
Infectious disease: & \\
tuberculosis & viral hepatitis \\
pericarditis & 2 \\
sarcoidosis & 2 \\
\hline
\end{tabular}




\section{Results}

The study comprised 203 eyes of 102 BSCR patients; one eye with an extensive corneal leucoma since childhood preventing fundus examination was not included. Full information on the clinical and functional investigations were not always available at the time of collection of the material (Table 1).

\section{MEDICAL AND OCULAR HISTORY}

A full medical history was recorded for 71 patients, but in most cases no relevant general disorder was identified (Table 2). In one patient with hilar lymphadenopathy the diagnosis of sarcoidosis was confirmed by biopsy and a positive Kveim test. Sarcoidosis was specifically sought in 38 other patients but was negative in all. The incidence of arterial hypertension in 16 patients, coronary artery disease in 5 , cerebrovascular accident in 2 , and retinal vein obstruction in 3 was higher than one would expect in a similar age group.

With the exception of a rather high incidence of open angle glaucoma there were no apparent ocular disorders associated with BSCR (Table 3).

A variety of ocular conditions were identified in family members but none of them showed evidence of BSCR. The dizygotic twin sister of a 52-year-old female patient was extensively examined; one sister had blood group $\mathrm{AB}+$ and the other one $\mathrm{A}+$, although both were identical HLA types. The twin sister had normal visual acuity in both eyes and no ocular complaints. Funduscopy revealed marked arteriosclerosis and two small perivascular haemorrhages but no signs of BSCR.

On assessment of the diagnosis BSCR, many patients already had a long history of visual symptoms (Table 4). Blurred vision and floaters were the most common complaints.

\section{CLINICAL EXAMINATION}

\section{Visual acuity}

There was a wide range of visual acuity on assessment of the diagnosis BSCR. However, most eyes $(73 \%)$ had a visual acuity of $6 / 18$ or better (Table 5 ).

In many patients the diagnosis BSCR was not made initially, since the clinical picture did not become well known until 1980 . The significance of the good visual acuity at the time of diagnosis is therefore greater when evaluated in relation to the duration of ocular symptoms (Table 6). Out of 84 eyes 33 had a visual acuity of $6 / 26$ or less when ocular complaints had been present for more than one year.

\section{Anterior segment and vitreous}

Details of the anterior segment were obtained in 68
Table 3 Ocular history in 79 patients with BSCR

\begin{tabular}{ll}
\hline & Eyes \\
\hline Open angle glaucoma & $16(1$ eye Scheie operation $)$ \\
Secondary glaucoma & 2 (2 trabeculectomies) \\
Cataract extraction & $5(3$ ECCE with IOL, 2 ICCE) \\
Rhegmatogenous retinal & 2 \\
$\quad$ detachment & 1 \\
Aphakic retinal detachment & 1 \\
Peripheral retinal breaks & 1 \\
Central retinal vein occlusion & 2 \\
Branch vein occlusion & 1 \\
Chloroquine keratopathy & 1 \\
Corneal leucoma (unknown & \\
$\quad$ aetiology) & \\
\hline
\end{tabular}

Table 4 Oculat symptoms at onset (81 BSCR patients)

\begin{tabular}{lc}
\hline & No. of patients \\
\hline Blurred vision & 58 \\
Floaters & 30 \\
Night blindness & 8 \\
Distorted vision & 4 \\
Photopsia & 4 \\
Irritation & 4 \\
Pain & 2 \\
\hline
\end{tabular}

Table 5 Visual acuity at initial ascertainment of BSCR

\begin{tabular}{lcc}
\hline & \multicolumn{2}{l}{ Eyes } \\
\cline { 2 - 3 } & No. & $\%$ \\
\hline $6 / 7 \cdot 5$ or more $(0 \cdot 8$ or more $)$ & 73 & 39 \\
$6 / 18-6 / 9(0 \cdot 4-0 \cdot 7)$ & 64 & 34 \\
$6 / 60-6 / 24(0 \cdot 1-0 \cdot 3)$ & 35 & 19 \\
$<6 / 60(<0 \cdot 1)$ & 15 & 8 \\
Total & 187 eyes* $^{*}$ & $100 \%$ \\
\hline
\end{tabular}

*One eye not in study.

patients. Only two of them showed redness of one or both eyes and signs of acute inflammation of the anterior segment. Eight patients had bilateral fine pigmented KP, and eight had very mild flare and cells in the anterior chamber of both eyes. In 13 eyes lens opacities were present but did not prevent adequate

Fig. 2 Clinical manifestations of birdshot chorioretinopathy. A and B: Patients aged 56 years (Gent). Typical symmetrical fundus pictures of BSCR. Small neovascular tuft at inferior margin of optic disc (arrow in B). C: Same fundus as in B. Radial linear structures in nasal periphery. Large choroidal vessels run over the lesions (arrow). D: Patient aged 37 years (Leiden). Large area of juxtapapillary atrophy with increased visibility of major choroidal vessels. E: Patient aged 51 years (Leiden). Sheathing of retinal vessel (arrow). F: Patent aged 64 years (Gent). Left fundus of BSCR patient with ocular history of 10 years' duration. The optic disc is pale, the retinal vessels are irregular and narrow, small haemorrhages are present. 


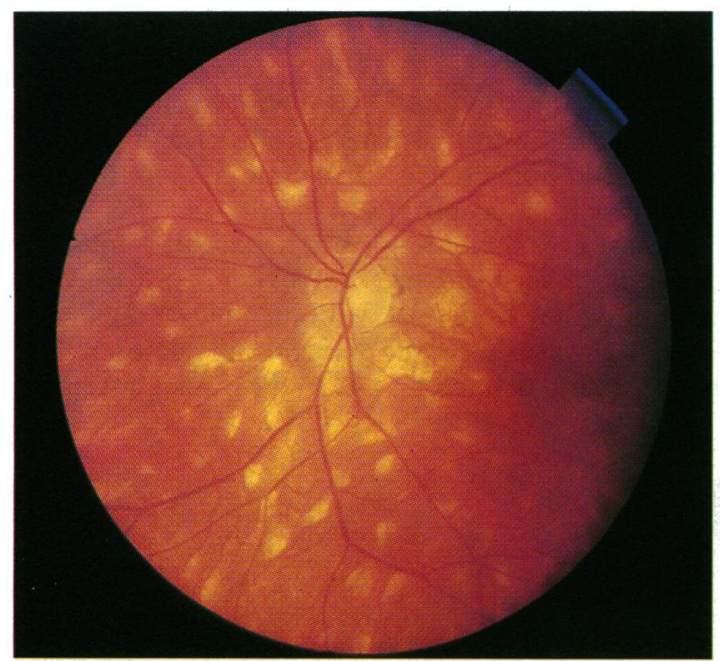

Fig. 2A

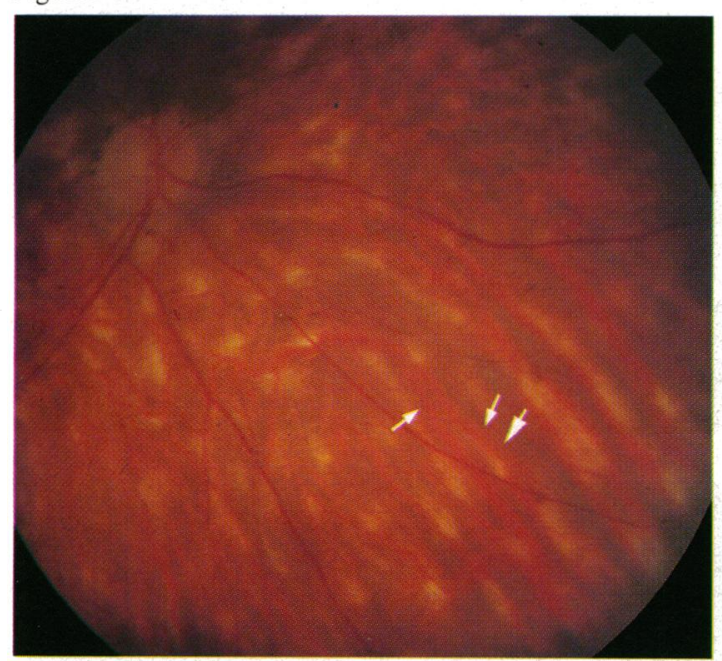

Fig. 2C

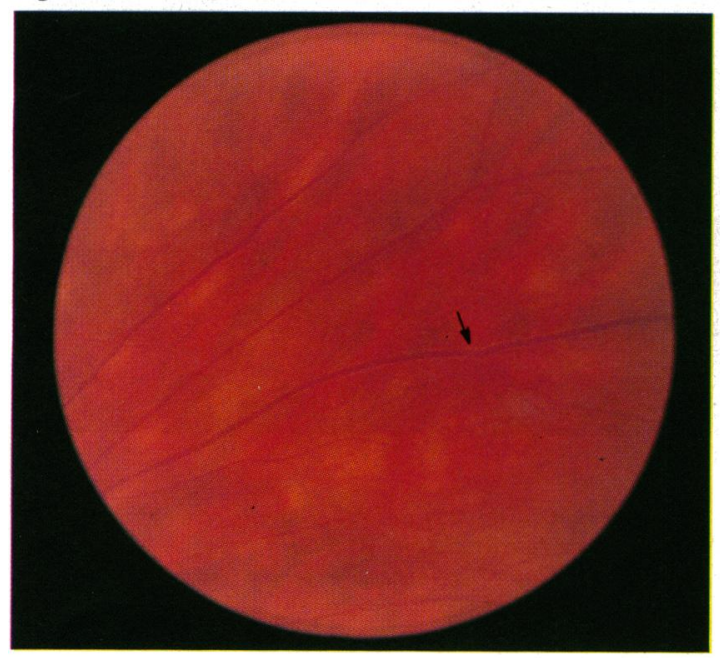

Fig. 2E

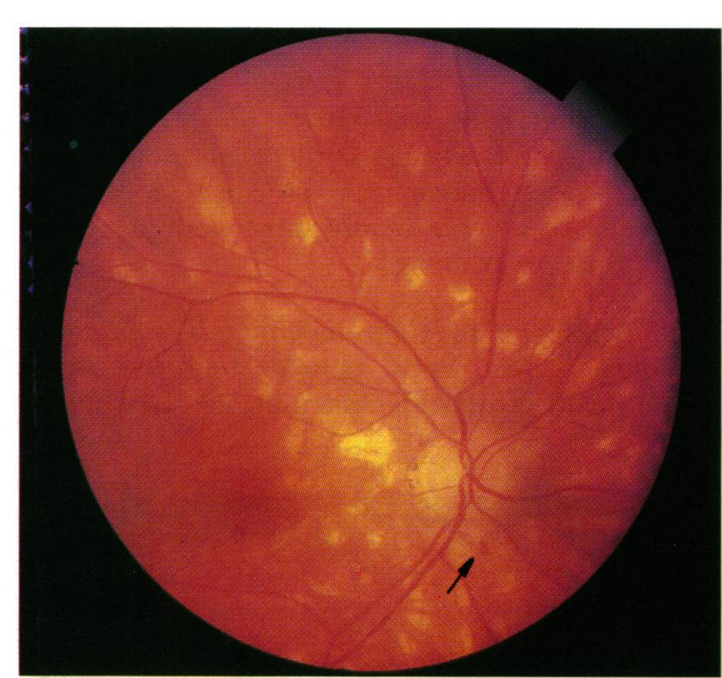

Fig. 2B

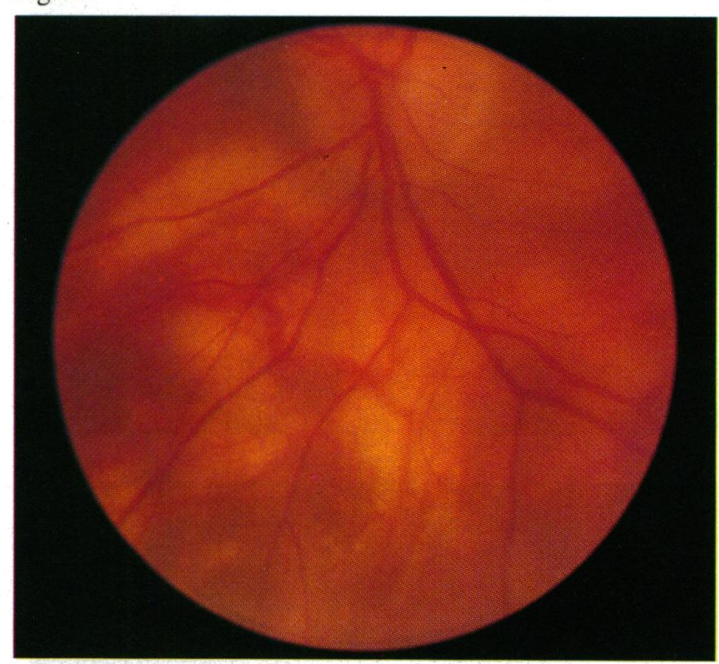

Fig. 2D

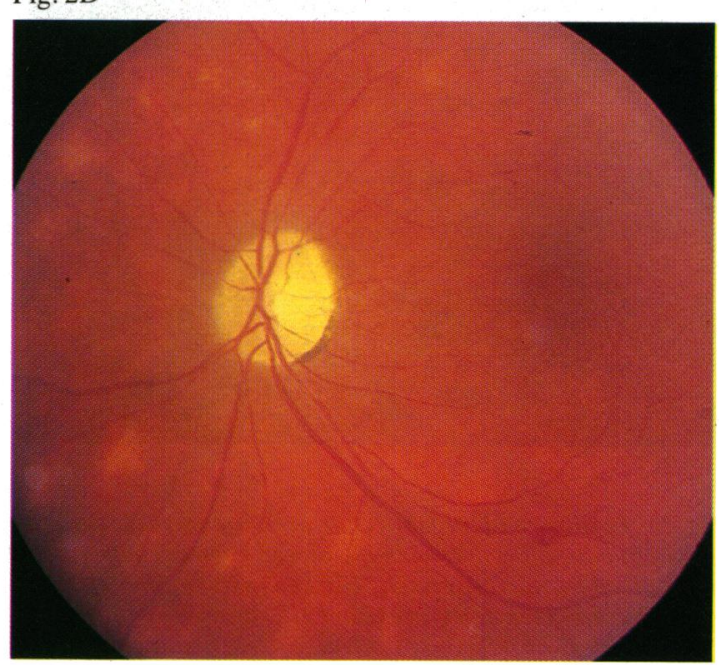

Fig. 2F

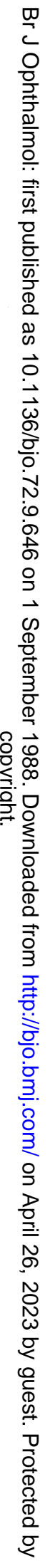


fundus examination. In 80 patients ( 159 eyes) examination of the vitreous was recorded: cells were seen in 121 eyes $(76 \cdot 1 \%)$ and opacities in 73 eyes $(45.9 \%)$. In total, signs of vitreous involvement were present in $83 \%$ of the eyes examined.

\section{Ophthalmoscopic and fluoroangiographic findings} Choroidal lesions. In 91 patients both eyes were symmetrically involved (colour plate $2 \mathrm{~A}, \mathrm{~B}$ ) whilst in
11 patients the condition was markedly asymmetrical. The following aspects of the lesions were considered: appearance, distribution, and fluoroangiographic behaviour.

In most eyes the lesions were remarkably uniform in colour, shape, and size (158 eyes, $77.8 \%$ ). Most frequently they were oval, with the longest diameter directed towards the optic disc and a diameter of less than $1 / 4$ disc diameter (DD); they had a cream

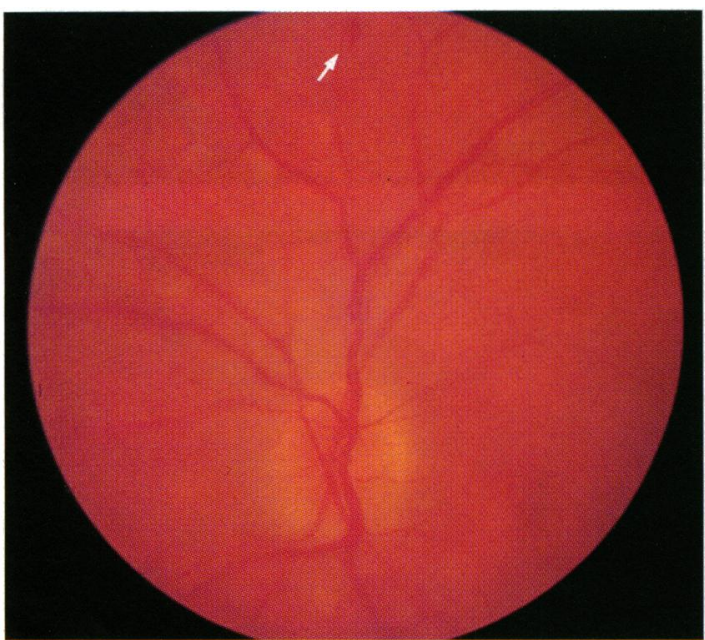

Fig. 3A

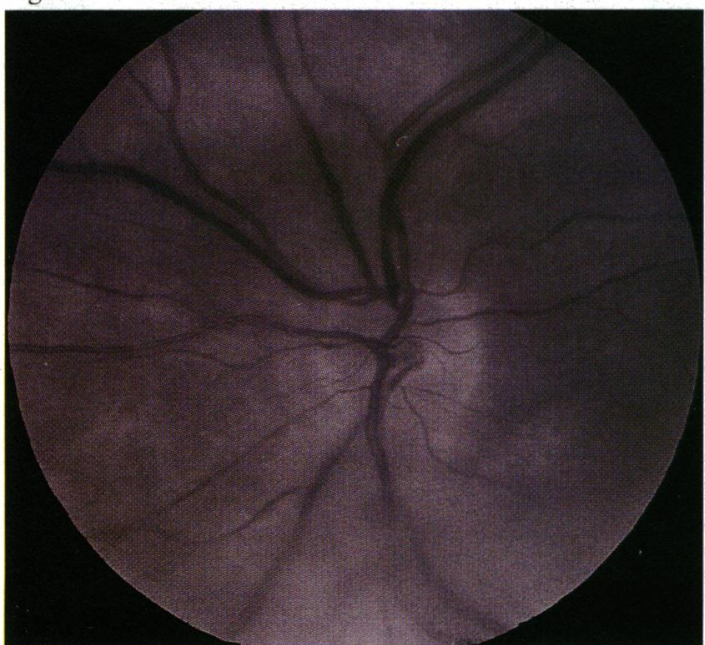

Fig. 3C

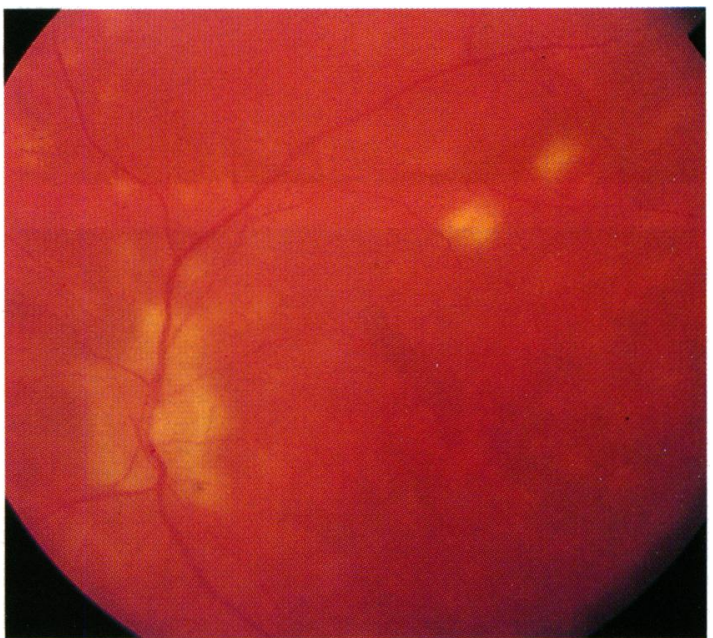

Fig. 3B

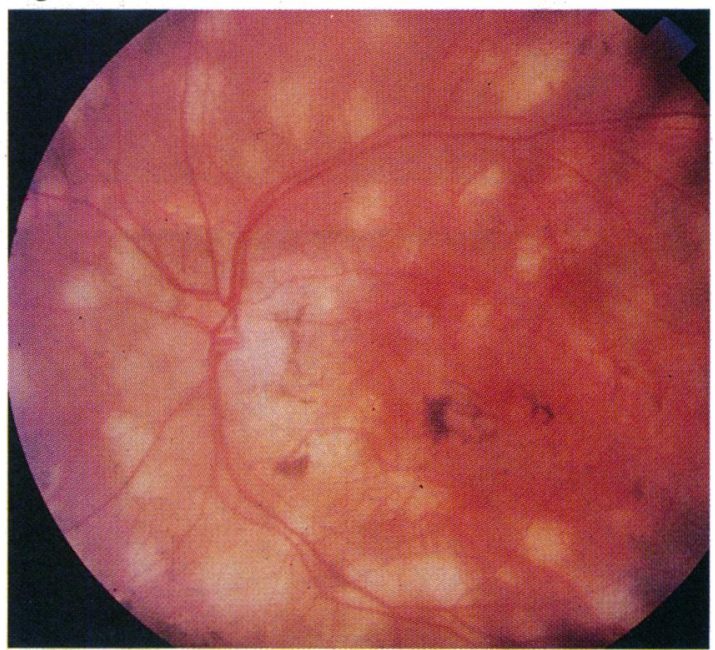

Fig. 3D

Fig. 3 Evolution of birdshot chorioretinopathy. A: Patient aged 44 years (Gent). Right eye in 1975, diagnosed as bilateral papillouveitis. Note disc oedema, retinal haemorrhage (arrow). BSCR flecks are hardly visible. B: Same fundus as A in 1985: pale optic disc, narrow vessels, marked juxtapapillary lesions; the birdshot flecks have become more clearly visible. C: Patient aged 34 years (Gent). Right eye in 1972 showing swollen optic disc; diagnosis: bilateral papillouveitis. D: Same fundus as C in 1985 (courtesy of B Snyers, Louvain), clearly showing birdshot flecks, narrowed arteries, small darkish dots as possible sign of redistribution of pigment. 
Table 6 Initial visual acuity and length of ocular history

\begin{tabular}{llccc}
\hline $\begin{array}{l}\text { Length of history at } \\
\text { initial ascertainment }\end{array}$ & \multicolumn{4}{l}{ Visual acuity (number of eyes) } \\
\cline { 2 - 5 } & $6 / 7 \cdot 5+$ & $6 / 9-6 / 18$ & $6 / 24-6 / 60$ & $<6 / 60$ \\
\hline 4 weeks or less & 15 & 4 & 1 & \\
1-5 months & 15 & 7 & & 1 \\
6-11 months & 14 & 10 & 6 & 6 \\
1-4 years & 7 & 25 & 14 & 5 \\
5 years and more & 11 & 8 & 8 & 3 \\
History not mentioned & 11 & 10 & 6 & 15 \\
Total & 73 & 64 & 35 & \\
\hline
\end{tabular}

coloured appearance and ill defined margins.

In a small number of patients the birdshot lesions were larger than $1 / 4 \mathrm{DD}$, were more round than oval, and did not show a radial distribution; however, their appearance was symmetrical.

More exceptionally, a few sharply defined white atrophic spots were seen among the typical birdshot lesions, mostly in the posterior pole (Fig. 3B).

Distribution. The densest concentration of lesions was seen around the optic disc and in the nasal periphery. In many eyes lesions were adjacent to the optic nerve head, giving the disc a typical petaloid appearance (Fig. 4). Sometimes the macular area was involved, but in most patients no flecks were present within the vascular arcades, apart from peripapillary lesions. In some eyes, with only a few or less prominent flecks, they were nearly always located in the inferonasal fundus.

In the majority of cases the lesions showed a well defined pattern radiating from the optic disc towards the periphery. There they often became confluent and formed long yellow-white streaks, following the large choroidal vessels (Fig. 2C).

Another common feature was the tendency of the lesions to progress into large geographic areas of choroidal depigmentation. These areas were most frequently found in the nasal periphery and around the optic disc. In these zones the large choroidal vessels were easily visible and appeared to be enlarged (Fig. 2).

In most eyes depigmentation of the lesions and of the atrophic areas was total and not associated with either pigment migration or hyperpigmentation. In some eyes there were tiny round, dark brown, sharply defined dots scattered over the fundus, unrelated to the lesions or depigmented areas (Fig. 4C).

Fluorescein angiography. In the majority of cases the birdshot spots were not evident in the early stage of angiography, becoming apparent in the venous phase as faint hyperfluorescent flecks which did not increase in intensity in the late phase (Fig. 4B). In fresh cases, however, the spots remained hypo-

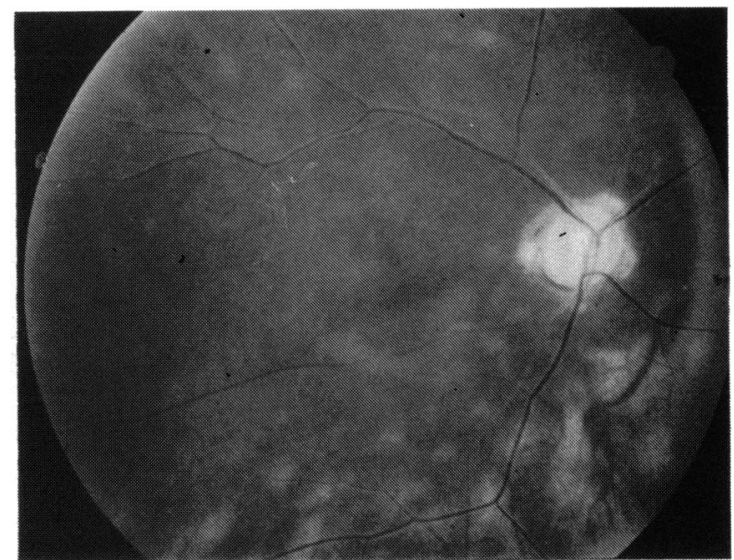

Fig. 4A Patient aged 51 years (courtesy of University Eye Clinic, Créteil). BSCR patient with petaloid aspect of optic disc due to lesions at the margin, sheathing of all large retinal vessels, cellophane maculopathy.

fluorescent during the dye transit (Fig. 4E). The lesions adjacent to the optic nerve head and occasionally those in the posterior pole were hypofluorescent (Fig. 4D). In a few eyes sharply circumscribed atrophic white lesions showed an early and bright hyperfluorescence.

Retinal vessels. There was marked narrowing of the retinal arteries in 124 eyes $(61 \%)$. In most cases this was associated with an irregularity in the calibre of the veins (Fig. 2F). In addition, small flame shaped haemorrhages (Figs. 2F, 3A) were present in 27 of these eyes, mostly in the posterior pole along the large temporal vessels or near the optic disc.

Retinal vascular leakage was a very common finding on fluorescein angiography (Fig. 4E). A

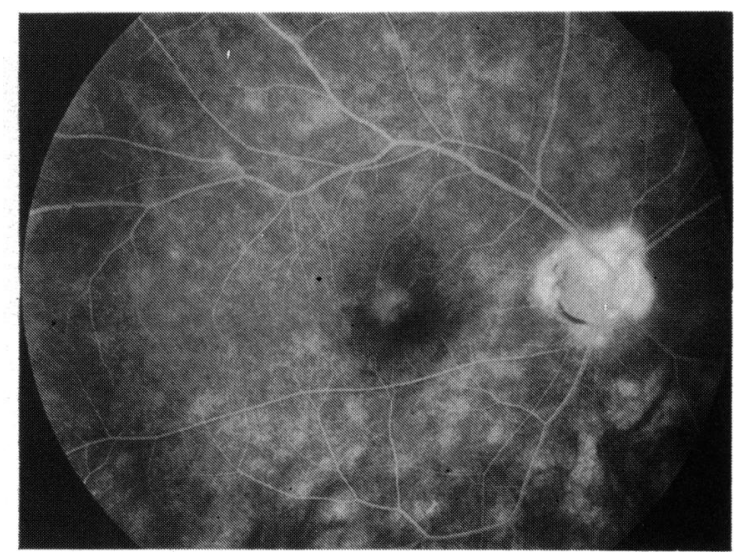

Fig. 4B Same fundus as in A. Fluoroangiography showing faint hyperfluorescence of the birdshot lesions; slight central macular oedema. 
Fig. 4C Patient aged 55 years (courtesy of A Leys, Leuven). BSCR patient with lesions adjacent to the optic disc (petaloid aspect) and tiny dark dots scattered over the fundus.

Fig. 4D Same fundus as C. Fluoroangiogram shows hypofluorescence of atrophic lesions adjacent to the optic disc and . of the dark dots.
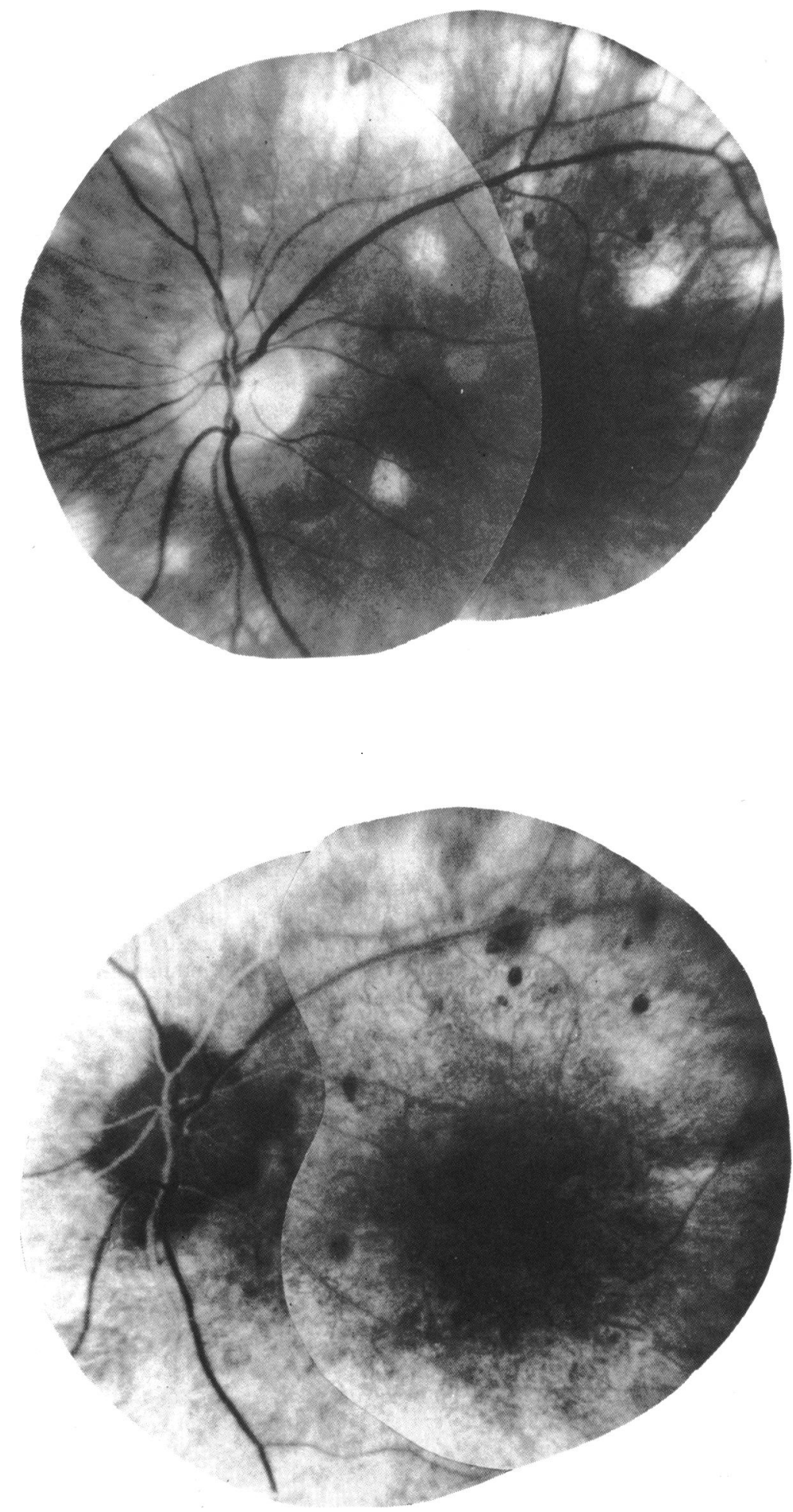


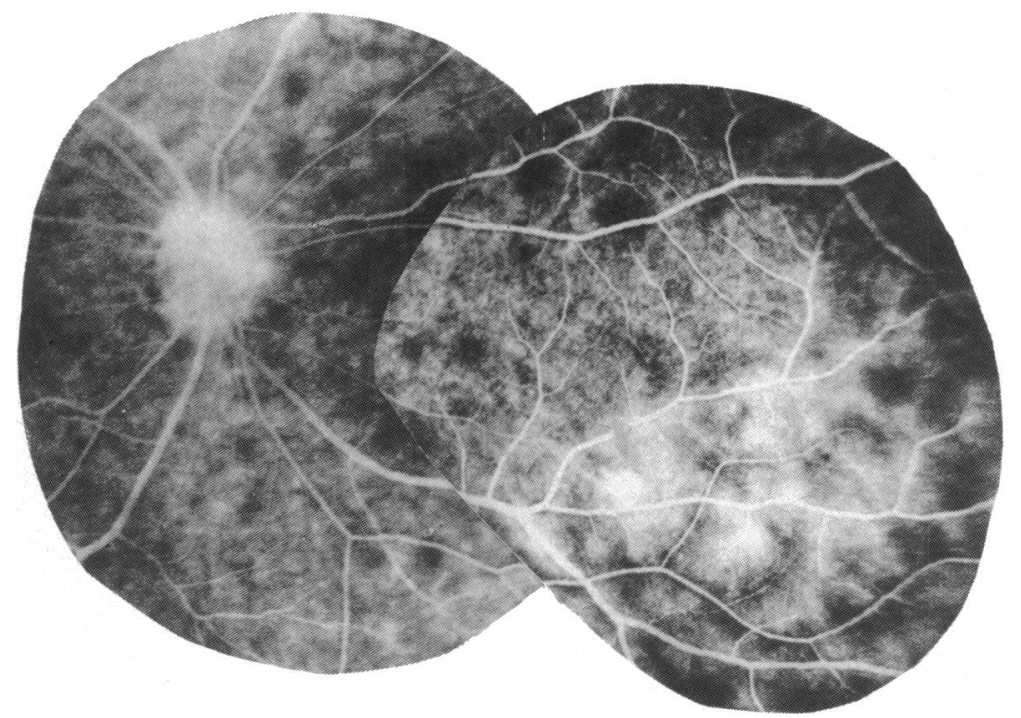

Fig. 4E Fluoroangiogram of a recently diagnosed case (Gent) of BSCR, showing localised hypofluorescence corresponding with BSCR lesions, capillary dye leakage at the optic disc and in nasal periphery.

localised staining of the wall of the large retinal veins was seen in 81 eyes $(40 \%)$. Profuse leakage from the retinal capillaries was the most constant finding, and cystoid macular oedema was present in 127 eyes $(62.6 \%)$ (Fig. 5A). In none of the patients was retinal capillary closure identified.

Optic disc. Apart from apparent blurred margins. due to lesions adjacent to the optic disc, 77 eyes $(38 \%)$ showed disc swelling. On fluorescein angiography there was evidence of capillary leakage at the optic nerve head in $38 \%$ of all eyes.

\section{ASSOCIATED FINDINGS}

These findings were related to complications of the disease (Table 7). The most frequent complications were epiretinal membranes and cellophane maculopathy (Fig. 6A and Fig. 4A), subretinal neovascular membranes (Figs. 6B, D), peripheral retinal and disc neovascularisation (Fig. 5B, Fig. 6E, F), vitreous haemorrhage, and optic atrophy (Fig. 2F). Proliferative retinopathy was particularly common and occurred in the absence of retinal capillary nonperfusion (Fig. 5C, D).

\section{Functional tests}

Perimetry, colour vision tests, dark adaptation and electrophysiology studies were performed on only some of the patients (Table 1).

Perimetry was normal in 15 out of 86 eyes, showed peripheral constriction in 30 , a central or paracentral scotoma in 28 , and an enlarged blind spot in 26 eyes.

The results of colour vision tests were normal in 21 out of 62 eyes, 23 eyes showed only a blue-yellow defect in 23 , and 12 eyes showed both blue-yellow and red-green defects.

Dark adaptation was normal in 9 out of 48 eyes

tested, borderline in 5, and pathological in 34 eyes $(70 \cdot 8 \%)$.

Visually evoked cortical responses were recorded in 60 eyes, 32 of which had abnormal amplitudes $(53 \%)$, while in another 13 eyes there was an increased latency.

The ERG was normal in 18 out of 84 eyes, in 4 eyes the absence of oscillatory potentials was the only abnormal finding, 14 eyes were borderline, and 46 eyes $(54.7 \%)$ had an abnormally low ERG. The EOG in 84 eyes showed a subnormal L/D ratio in 60 eyes (Table 8).

\section{HLA typing}

Data on HLA typing were available in 48 patients. In 43 the complete HLA A and HLA B loci were screened and in an additional 5 only the HLA A29 was sought. Forty-six out of these 48 BSCR patients $(95 \cdot 8 \%)$ carried the antigen HLA A29.

\section{EVOLUTION AND MANAGEMENT}

There was no uniformity in the management of the disease in this large group of patients, which reflects their origin from 14 different eye departments. A variety of therapies was used for posterior segment inflammation, including corticosteroids, nonsteroidal anti-inflammatory drugs (indomethacin), immunosuppressive drugs (azathioprine, cyclophosphamide, cyclosporin A), and a variety of antibiotics.

In many cases the indication for treatment was not clear. Owing to different criteria for management of the disease it was difficult to evaluate the influence of therapy on the visual outcome. The data on a group of 27 patients with a follow-up of five years or more 


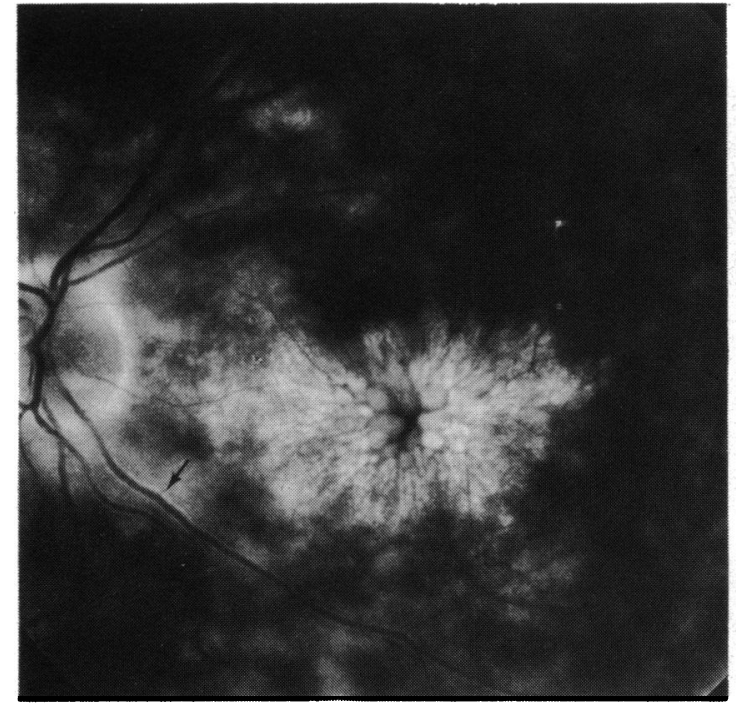

Fig. 5A Patient aged 68 years (Gent). BSCR with severe cystoid macular oedema. Note also hyperfluorescence of the venous vessel wall (arrow).

did not clearly indicate whether steroids and other anti-inflammatory and immunosuppressive drugs were beneficial in BSCR (Table 9).

Argon laser photocoagulation was applied to 17 eyes for treatment of subretinal neovascular membranes ( 7 eyes), vitreous haemorrhage (4 eyes),

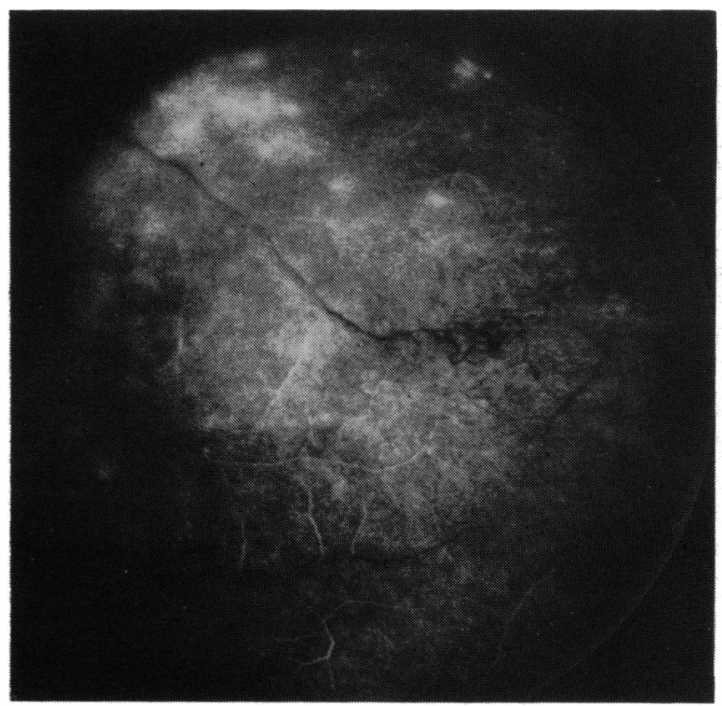

Fig. 5B Same patient as in Fig. $2 A, B$ with relapsing vitreous haemorrhage in right eye. After clearing of the haemorrhage a teleangiectatic lesion is seen in the temporal periphery.

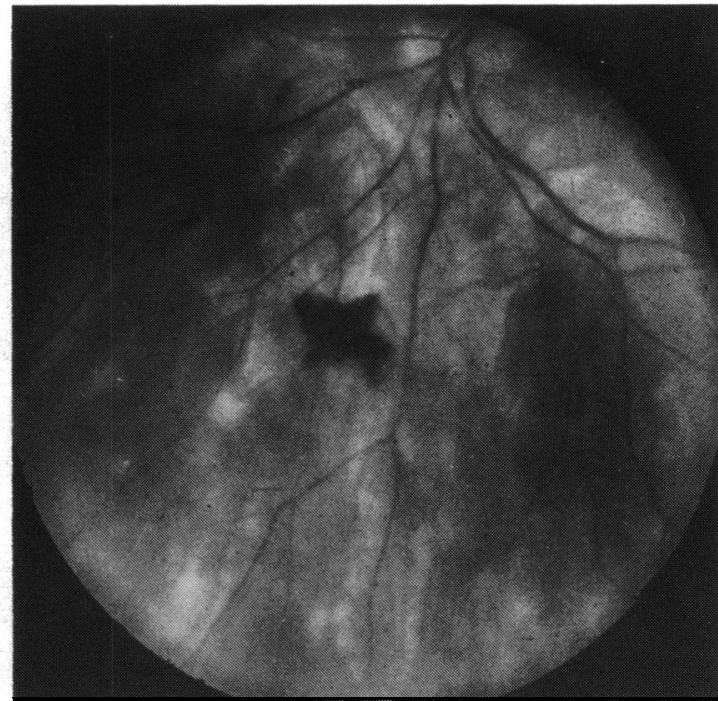

Fig. 5C Patientaged 55 years (Gent). BSCR with irregular calibre of vessels and a preretinal haemorrhage.

macular oedema ( 3 eyes), and peripheral retinal breaks or peripheral degeneration ( 3 eyes).

The review period for 62 patients ranged from one month to 13 years. After an evolution of five years or more half of the eyes have maintained a visual acuity of $6 / 18$ or better (Table 10). Loss of visual acuity was

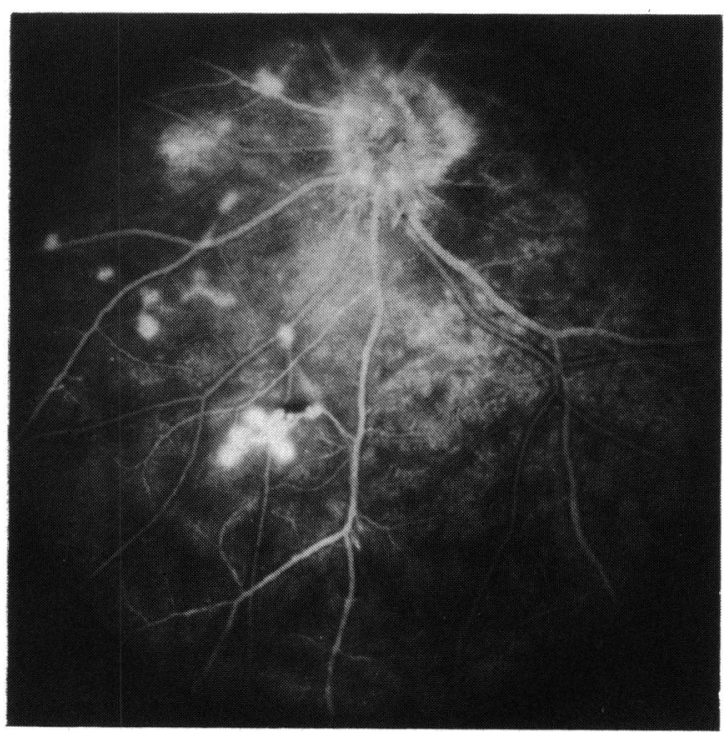

Fig. 5D Same fundus as 5C. Fluoroangiogram shows multiple sites of retinal neovascularisation and widespread capillary dilatation, but no evidence of capillary closure. 
Table 7 Complications associated with BSCR

\begin{tabular}{lr}
\hline Total number of eyes with BSCR & 203 \\
Epiretinal membrane & 20 \\
Retinal neovascularisation & 15 \\
Vitreous haemorrhage & 5 \\
Subretinal neovascular membrane & 4 \\
Parapapillary & 8 \\
Macular & 7 \\
Optic atrophy & \\
\hline
\end{tabular}

Table 8 EOG in 84 eyes with BSCR

\begin{tabular}{ll}
\hline$L / D$ ratio & Number of eyes \\
\hline $171-200 \%$ & 22 \\
$151-170 \%$ & 11 \\
$131-150 \%$ & 23 \\
$111-130 \%$ & 15 \\
$<110 \%$ & 11 \\
\hline
\end{tabular}

due to cystoid macular oedema, epiretinal membrane in the macula, macular hole, subretinal neovascular membrane, macular scar, and cataract. Vitreous haemorrhage and vitreous floaters were important causes of visual loss in the initial stages of the disease but did not contribute to the final visual outcome in the group of patients with a minimum follow-up period of five years.

Improvement of visual acuity was seen in 13 eyes as a result of clearing of vitreous haemorrhage (3 eyes), removal of cataract ( 3 eyes), laser photocoagulation of subretinal new vessels ( 2 eyes), and regression of inflammatory signs ( 5 eyes).

A few eyes showed a remarkable evolution in the appearance of the hypopigmented spots (Fig. 3). Five patients initially had no clear evidence of birdshot spots in the fundus when they presented with papillitis, retinal vasculitis, and varying degrees of vitritis in both eyes. The typical fundus picture of BSCR did not appear until several years later, mostly when the signs of acute inflammation had resolved.

\section{Discussion}

\section{MEDICAL AND OCULAR ASSOCIATIONS}

The apparently high prevalence of vascular diseases might indicate that BSCR is associated with a general vascular disorder. No other systemic diseases seem to be relevant to the disease. Because Gass ${ }^{2}$ stressed the association of BSCR with vitiligo, this was especially sought; however, only one out of 102 patients was known to have depigmentation of the skin and only after exposure to the sun. Moreover, Wagoner et $\dot{a} l .{ }^{18}$ on examination of 223 patients with vitiligo, found evidence of BSCR in only one. Since multifocal choroidal disease is known to occur in sarcoidosis, ${ }^{519}$ at least 38 patients were fully investigated by
Table 9 Visual outcome in 27 BSCR patients after five years ormore

\begin{tabular}{|c|c|c|c|c|c|}
\hline $\begin{array}{l}\text { Patient } \\
\text { no. }\end{array}$ & $\begin{array}{l}\text { Initial } \\
V A\end{array}$ & $\begin{array}{l}\text { Final } \\
V A\end{array}$ & $\begin{array}{l}\text { Cause of } \\
\text { visual loss }\end{array}$ & $\begin{array}{l}\text { Follow- } \\
\text { up } \\
\text { (years) }\end{array}$ & Treatment \\
\hline 1 & $6 / 18$ & $6 / 24$ & CME & 8 & Steroids, laser LE \\
\hline 2 & $\begin{array}{l}6 / 24 \\
6 / 12\end{array}$ & $\begin{array}{l}C F \\
6 / 6\end{array}$ & $\begin{array}{l}\text { CME } \\
\text { CME }\end{array}$ & 10 & Steroids \\
\hline & $6 / 12$ & $6 / 6$ & CME & & \\
\hline 3 & $\begin{array}{l}\mathrm{CF} \\
\mathrm{CF}\end{array}$ & $\begin{array}{l}\mathrm{CF} \\
\mathrm{CF}\end{array}$ & $\begin{array}{l}\text { Macular scar } \\
\text { Subretinal } \\
\text { neovasc }\end{array}$ & 5 & Laser LE \\
\hline 4 & $\begin{array}{l}6 / 6 \\
6 / 7 \cdot 5\end{array}$ & $\begin{array}{l}\text { CF } \\
\text { CF }\end{array}$ & $\begin{array}{l}\text { CME } \\
\text { CME }\end{array}$ & 8 & $\begin{array}{l}\text { Steroids, } \\
\text { cyclophosphamide. } \\
\text { cyclosporin A+ }\end{array}$ \\
\hline 5 & $\begin{array}{l}6 / 12 \\
6 / 12\end{array}$ & $\begin{array}{l}6 / 60 \\
6 / 60\end{array}$ & $\begin{array}{l}\mathrm{CME} \\
\mathrm{CME}\end{array}$ & 6 & Steroids \\
\hline 6 & $\begin{array}{l}6 / 18 \\
6 / 6\end{array}$ & $\begin{array}{l}\text { CF } \\
6 / 12\end{array}$ & $\begin{array}{l}\mathrm{CME} \\
\mathrm{CME}\end{array}$ & 6 & $\begin{array}{l}\text { Steroids, } \\
\text { cyclosporin A }\end{array}$ \\
\hline 7 & $\begin{array}{l}6 / 12 \\
6 / 6\end{array}$ & $\begin{array}{l}6 / 9 \\
6 / 6\end{array}$ & $\begin{array}{l}\text { Vitreous } \\
\text { opacities }\end{array}$ & 9 & Steroids \\
\hline 8 & $\begin{array}{l}6 / 6 \\
6 / 5\end{array}$ & $\begin{array}{l}6 / 60 \\
6 / 9\end{array}$ & $\begin{array}{l}\text { CME + pucker } \\
\text { CME+ } \\
\text { cellophane }\end{array}$ & 5 & Steroids \\
\hline 9 & $\begin{array}{l}6 / 9 \\
6 / 12\end{array}$ & $\begin{array}{l}6 / 12 \\
6 / 9\end{array}$ & $\begin{array}{l}\text { CME } \\
\mathrm{CME}\end{array}$ & 5 & Indomethacin \\
\hline 10 & $\begin{array}{l}\text { CF } \\
\mathrm{CF}\end{array}$ & $\begin{array}{l}6 / 12 \\
\mathrm{CF}\end{array}$ & $\begin{array}{l}\text { CME } \\
\text { Cataract + } \\
\text { retinal } \\
\text { detachment }\end{array}$ & 5 & Steroids \\
\hline 11 & $\begin{array}{l}6 / 12 \\
6 / 9\end{array}$ & $\begin{array}{l}6 / 18 \\
6 / 60\end{array}$ & $\begin{array}{l}\text { PE alteration } \\
\text { Subretinal } \\
\text { neovasc. }\end{array}$ & 6 & $\begin{array}{l}\text { Sphiramycin, } \\
\text { stcroids, laser LE }\end{array}$ \\
\hline 12 & $\begin{array}{l}6 / 12 \\
\mathrm{CF}\end{array}$ & CF & $\begin{array}{l}\text { CME } \\
\text { CME }\end{array}$ & 6 & \\
\hline 13 & $\begin{array}{l}6 / 6 \\
6 / 60\end{array}$ & $\begin{array}{l}6 / 6 \\
6 / 60\end{array}$ & $\begin{array}{l}\text { CME } \\
\text { CME }\end{array}$ & 11 & $\begin{array}{l}\text { Steroids, laser macula } \\
\text { LE }\end{array}$ \\
\hline 14 & $6 / 9$ & $6 / 60$ & $\begin{array}{l}\text { CME+ } \\
\text { vitreous } \\
\text { haemorrh. }\end{array}$ & 9 & $\begin{array}{l}\text { Steroids, } \\
\text { azathioprine }\end{array}$ \\
\hline 15 & $\begin{array}{l}6 / 9 \\
6 / 9 \\
6 / 9\end{array}$ & $\begin{array}{l}6 / 24 \\
\mathrm{HM} \\
6 / 60\end{array}$ & $\begin{array}{l}\text { CME } \\
\text { CME } \\
\text { CME }\end{array}$ & 13 & $\begin{array}{l}\text { Steroids, } \\
\text { azathioprine }\end{array}$ \\
\hline 16 & $6 / 18$ & $6 / 60$ & cME+ & 5 & Steroids, IOL RE \\
\hline & $6 / 12$ & $6 / 36$ & $\begin{array}{l}\mathrm{CME}+ \\
\text { cataract }\end{array}$ & & \\
\hline 17 & $\mathrm{CF}$ & $\mathrm{CF}$ & Optic atrophy & 5 & None \\
\hline 18 & $\begin{array}{l}\text { CF } \\
6 / 9\end{array}$ & $\begin{array}{l}\text { LP } \\
6 / 9\end{array}$ & $\begin{array}{l}\text { Optic atrophy } \\
\text { CME }\end{array}$ & 5 & Steroids \\
\hline & $6 / 6$ & $6 / 9$ & $\begin{array}{l}\mathrm{CME}+ \\
\text { cellophane }\end{array}$ & & \\
\hline 19 & $6 / 9$ & $6 / 9$ & $\begin{array}{l}\text { Secondary } \\
\text { glaucoma }\end{array}$ & 5 & $\begin{array}{l}\text { Trabeculectomy } \\
\text { RE+LE }\end{array}$ \\
\hline & HM & HM & $\begin{array}{l}\text { Secondary } \\
\text { glaucoma }\end{array}$ & & \\
\hline 20 & $\begin{array}{l}6 / 18 \\
6 / 7 \cdot 5\end{array}$ & $\begin{array}{l}6 / 5 \\
6 / 6\end{array}$ & & 7 & $\begin{array}{l}\text { Steroids, systemic + } \\
\text { topical }\end{array}$ \\
\hline 21 & $\begin{array}{l}6 / 24 \\
6 / 24\end{array}$ & $\begin{array}{l}6 / 24 \\
6 / 18\end{array}$ & $\begin{array}{l}\text { CME } \\
\text { CME }\end{array}$ & 10 & Steroids \\
\hline 22 & $\begin{array}{l}6 / 6 \\
6 / 7 \cdot 5\end{array}$ & $\begin{array}{l}6 / 6 \\
6 / 6\end{array}$ & & 11 & Steroids retrobulbar \\
\hline 23 & $\begin{array}{l}6 / 4 \\
6 / 4\end{array}$ & $\begin{array}{l}6 / 4 \\
6 / 4\end{array}$ & & 9 & Steroids topical \\
\hline 24 & $\begin{array}{l}6 / 60 \\
6 / 12\end{array}$ & $\begin{array}{l}6 / 60 \\
6 / 12\end{array}$ & $\begin{array}{l}\text { CME } \\
\text { CME }\end{array}$ & 8 & $\begin{array}{l}\text { Steroids, } \\
\text { azathioprine, } \\
\text { indomethacin }\end{array}$ \\
\hline 25 & $\begin{array}{l}6 / 6 \\
6 / 6\end{array}$ & $\begin{array}{l}6 / 6 \\
6 / 12\end{array}$ & & 5 & Steroids \\
\hline 26 & $\begin{array}{l}6 / 7 \cdot 5 \\
6 / 18\end{array}$ & $\begin{array}{l}6 / 12 \\
6 / 18\end{array}$ & $\begin{array}{l}\text { PE alterations } \\
\text { Subretinal } \\
\text { neovasc. }\end{array}$ & 6 & $\begin{array}{l}\text { Steroids, laser } \\
\quad \text { subretinal neovasc. }\end{array}$ \\
\hline 27 & $\begin{array}{l}6 / 36 \\
6 / 24\end{array}$ & $\begin{array}{l}\text { CF } \\
\text { CF }\end{array}$ & $\begin{array}{l}\text { CME } \\
\text { CME }\end{array}$ & 6 & Steroids, laser LE \\
\hline
\end{tabular}

$\mathrm{CME}=$ cystoid macular oedema $. \mathrm{CF}=$ counting fingers. 
Table 10 Visual acuity at last control (numbers of eyes)

\begin{tabular}{lllcl}
\hline Visual acuity & \multicolumn{4}{l}{ Follow-up period } \\
\cline { 2 - 5 } & 1 year & 2 years & 5 years & 8 years \\
\hline $6 / 7 \cdot 5+$ & 21 & 17 & 3 & 8 \\
$6 / 18-6 / 9$ & 23 & 25 & 13 & 3 \\
$6 / 60-6 / 24$ & 14 & 12 & 6 & 7 \\
$<6 / 60$ & 10 & 3 & 10 & 4 \\
\hline
\end{tabular}

means of chest $x$-ray, full blood counts, biochemical tests including calcium and angiotensin-converting enzyme, Kveim test, and sometimes biopsy of skin lesions. However, in only one was evidence of sarcoidosis found; one other case of BSCR associated with sarcoidosis has been reported in Japan. ${ }^{19}$

There was a particularly high incidence of open angle glaucoma (15 eyes, 19\%) not associated with pigment dispersion in the anterior chamber and without evidence of elevated venous episcleral pressure.

Two of the 79 patients with available ocular history had a rhegmatogenous retinal detachment, and another patient had laser treatment for a peripheral retinal hole with operculum. The occurrence of rhegmatogenous retinal detachment in BSCR has been recorded ${ }^{161111}$ and is a recognised complication of uveitis. ${ }^{20}$ Rhegmatogenous retinal detachment may complicate BSCR due to alterations and shrinkage. The finding of minimal involvement of the anterior segment is consistent with the other clinical reports on BSCR, as is the case with the high percentage of vitreous opacities.

In general, the medical history and examinations were not helpful in establishing an aetiological factor for BSCR.

\section{FUNDUS CHANGES}

The ophthalmoscopic and fluorescein-angiographic findings of the birdshot lesions, retinal vasculopathy, and most of the complications have been previously reported.

The depigmented choroidal lesions are the most prominent feature of BSCR. Several suggestions have been made regarding the pathogenesis of these lesions, depending on speculations as to their nature and on their level in the eye. According to Ryan and Maumenee' 'the depigmented spots may be related to previous accumulation of fluid or to inflammatory foci in the choroid or in the retinal pigment epithelium'. Gass, ${ }^{2}$ however, finds the patches 'unlike most other infiltrative or atrophic hypopigmented fundus lesions' because they are not elevated as they are with a nodular inflammatory cellular infiltrate, nor are they depressed as in the case of atrophy of the choroid and retina. He suggests that they are "caused by focal depigmentation of the choroidal melanocytes' and compares the lesions with vitiligo of the skin. We could not establish a relation with vitiligo in our patients. Moreover, the birdshot lesions have a distribution which does not correspond with the diffuse presence of the melanocytes in the choroid.

Several findings suggest that the birdshot lesions are located in the outer choroid and are associated with the large choroidal vessels. On many occasions large choroidal vessels are clearly seen to cross over the lesions (Fig. 2C). The birdshot lesions show a radial arrangement round the optic disc; this distribution corresponds most with the pattern of the large choroidal vessels and more specifically the choroidal veins. Most eyes showed macular sparing by the birdshot lesions, an area which in most people is relatively free of large choroidal veins. However, the lack of lesions in the central fundus is not a constant feature, and one case has been reported in which the macula was the most affected site. ${ }^{14}$ Very often the more peripheral lesions are confluent and form elongated yellow-white streaks parallel to the choroidal vessels, suggestive of vascular sheathing. Their predominant occurrence nasally inferior to the optic disc and the development of confluent lesions in the inferior nasal quadrant have also been reported by other authors. ${ }^{814}$ The large size and high density of both choroidal veins and lesions at this site may be significant. The deep location of the lesions would explain their indistinct appearance and the lack of secondary retinal pigment-epithelial reaction or disturbance even in longstanding cases. The mild late phase hyperfluorescence of the birdshot lesions is in accordance with a deep seated inflammatory focus which gradually accumulates fluorescein.

Retinal vasculopathy was a major feature of BSCR in this group of 203 eyes, manifest as cystoid macular oedema in 127 eyes $(62.6 \%)$ and perivascular leakage in 81 eyes $(40 \%)$. In several eyes the retinal vasculitis associated with vitreous cells and papillitis was the presenting sign of the disease.

Retinal neovascularisation occurred in 15 eyes in the absence of retinal capillary closure, making it unlikely that the growth was in response to

Fig. 6 Complications in birdshot chorioretinopathy. A: Patient aged 56 years (Gent). Epiretinal membrane superior to optic disc (arrows). B: Patient aged 58 years (courtesy of P Amalric, Albi). BSCR with juxtapapillary subretinal neovascularisation. C: Patient aged 52 years (courtesy of P Amalric, Albi). Left eye in 1981: note white birdshot lesion under the macula. D: Same fundus as $C$ in 1983: subretinal neovascularisation has developed at the site of the birdshot lesion. E: Patient aged 44 years (courtesy of JShilling, London). BSCR with prepapillary neovascularization (July 1978). F: Same fundus as $E$. Peripheral retinal neovascularisation. 


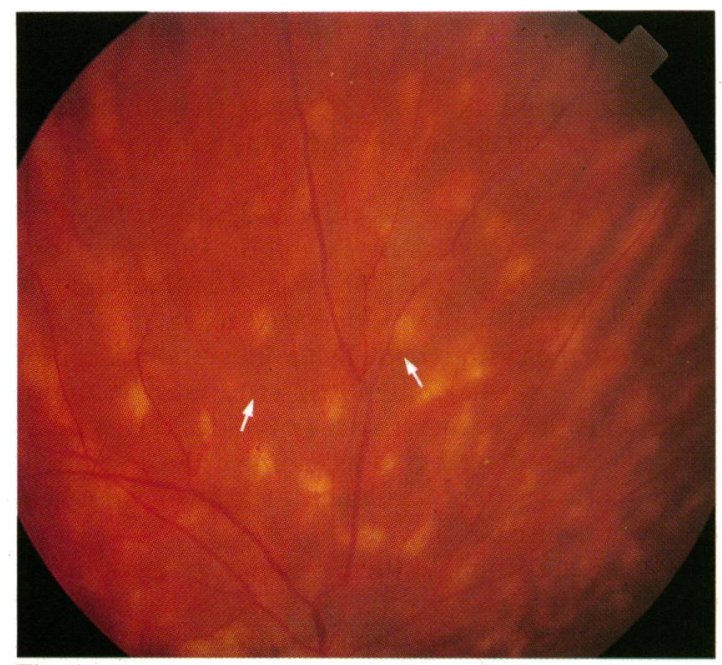

Fig. 6A

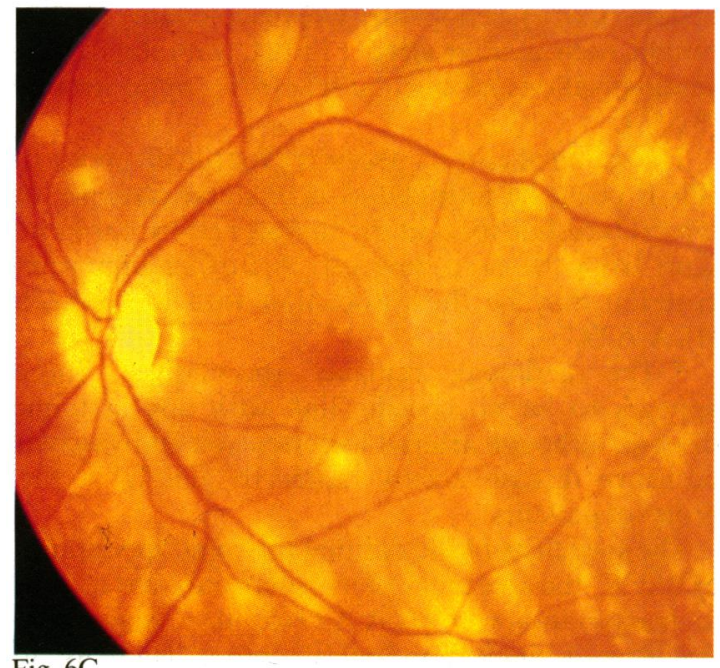

Fig. 6C

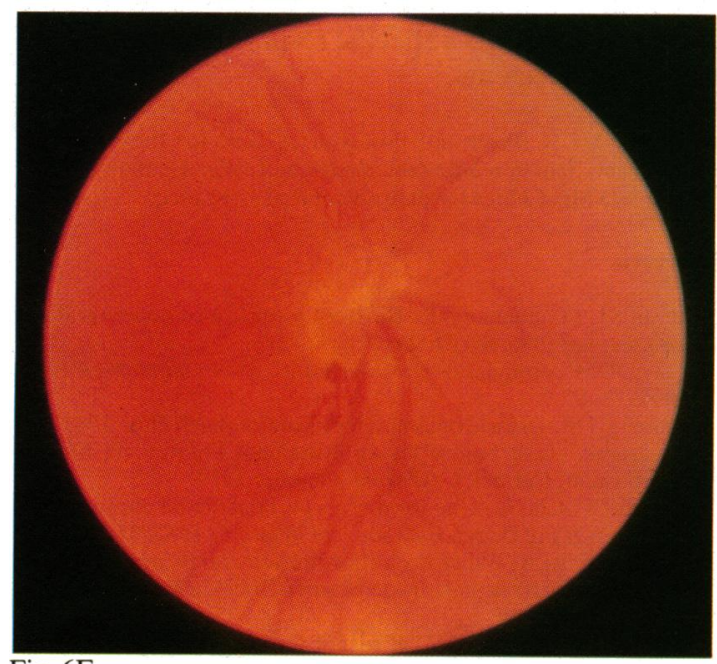

Fig. 6E

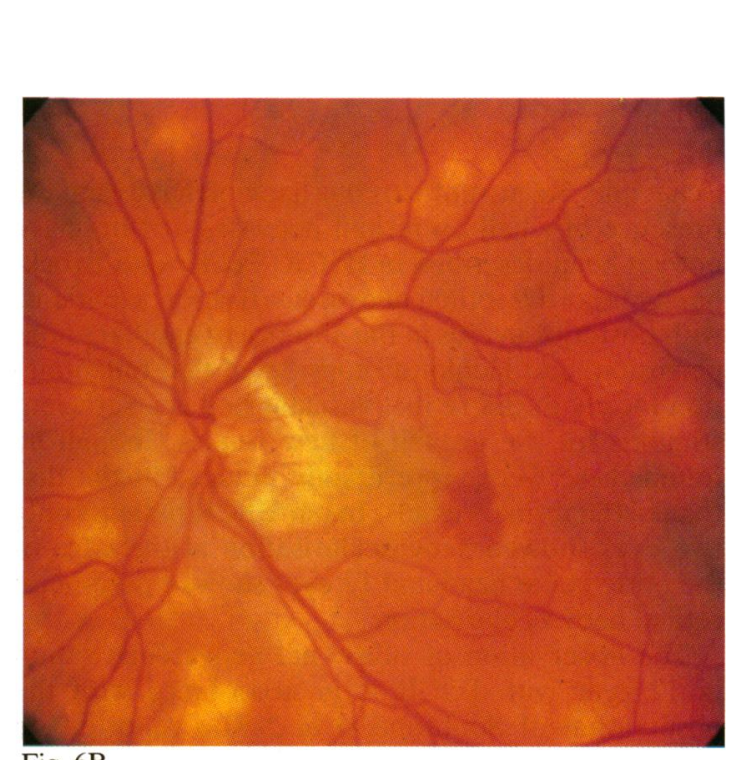

Fig. 6B

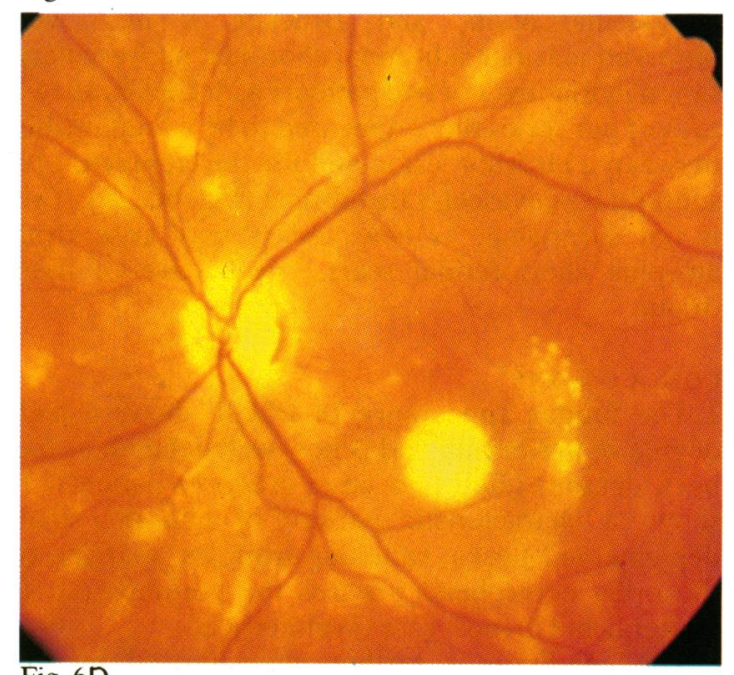

Fig. 6D

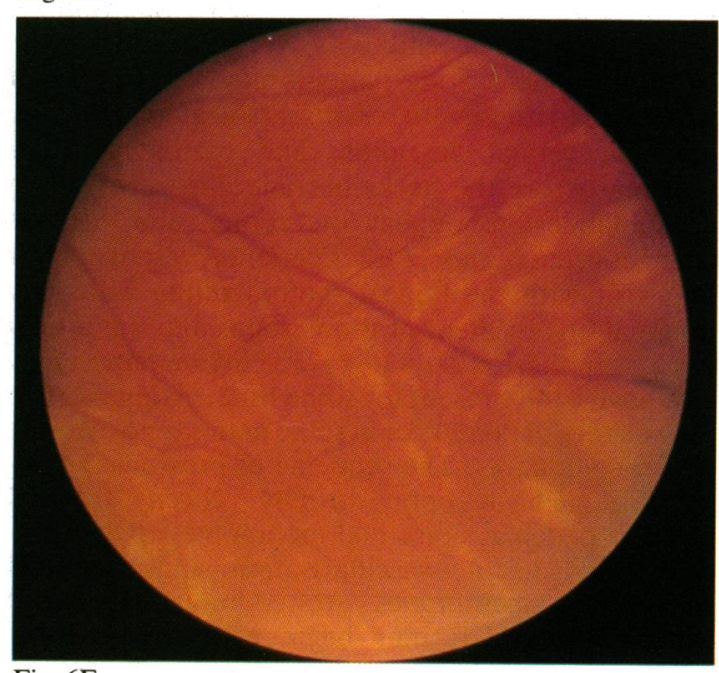

Fig. $6 \mathrm{~F}$ 
ischaemia. Recurrent vitreous haemorrhages and the presence of small preretinal neovascular tufts have not yet been described in BSCR. Felder and Brockhurst ${ }^{21}$ reported retinal neovascularisation in patients with posterior uveitis in the absence of capillary nonperfusion, and Henkind ${ }^{22}$ considered that inflammation locally in the retinal vascular bed is a sufficient stimulus for the growth of new vessels, though he found these were more readily induced at the disc than in the retinal vessels. In our BSCR patients only two eyes showed neovascularisation at the edge of the optic nerve head and 13 eyes showed peripheral retinal neovascularisation.

The observation of subretinal neovascularisation in 12 eyes with BSCR is in accordance with the observation of Soubrane et al. ${ }^{8}$ who reported on three BSCR patients with juxtapapillary subretinal neovascularisation, and Brucker et al., who observed macular subretinal choroidal neovascularisation in four eyes of two patients with BSCR. In two eyes of our series there appeared to be a relationship between a birdshot lesion and the development of a subretinal neovascular membrane (Fig. 6C, D). This is not surprising, as new vessels may arise from atrophic chorioretinal scars, irrespective of their origin.

\section{CONCLUSIONS}

1. The fundus appearance of BSCR shows a high degree of uniformity and is now well defined, as has been demonstrated in a large group of patients. It shows a characteristic pattern of multiple small depigmented flecks, radiating from the margins of the optic nerve head towards the periphery. It is bilateral and in most cases symmetrical.

The condition is further characterised by the presence of various inflammatory signs, mainly in the posterior segment and only very seldom in the anterior segment. Some patients may initially present with a mild to severe vitritis associated with disc oedema, retinal vasculitis, and cystoid macular oedema before the flecks become apparent; as the choroidal lesions appear the retinal and vitreous changes often regress. Other patients present at their first visit with the typical spotted retina with only minimal involvement of the vitreous and the retinal vessels. In these cases a low grade inflammation may also have been present for some time, giving rise to a long history of floaters or in some patients not causing ocular complaints. The sequelae of previous inflammation, such as optic atrophy, chronic cystoid macular oedema, epiretinal membranes, peripheral retinal and disc neovascularisation, and subretinal neovascular membranes are common. It would appear that BSCR may begin with simultaneous inflammatory reactions in the vitreous, the retina, and the choroid, and that after a period of more or less active inflammation the condition tends to stabilise.

The disease is rare, as only 102 cases of typical BSCR were collected in 14 major European eye clinics during the period 1980-6, and it affects people in middle life without predilection for sex.

2. From the various clinical manifestations it is now possible to consider diagnostic criteria. The major criterion is the characteristic spotted fundus appearance associated with evidence of posterior segment inflammation and/or evidence of known complications of the disease.

Ranged according to their frequency, the ophthalmoscopic signs are vitritis $(83 \%)$, cystoid macular oedema $(62 \cdot 6 \%)$, arteriolar narrowing and irregularity of veins $(61 \%)$, retinal vasculitis $(40 \%)$, disc oedema $(38 \%)$, cellophane-like maculopathy $(10 \%)$, retinal neovascularisation $(7 \cdot 5 \%)$, subretinal neovascularisation and macular scar $(6 \%)$, optic atrophy $(3 \cdot 5 \%)$.

The minimal criteria necessary for the diagnosis of BSCR could be formulated as bilateral presence of typical birdshot spots in the fundus and two or more signs from the preceding list. A further important criterion may be the association with the antigen HLA A29.

3. The aetiology remains speculative. There appears to be no specific link with any systemic disease, although arterial hypertension and vascular occlusive disease occurs rather frequently in this group of patients.

The specificity of the ophthalmoscopic appearance of BSCR, the constancy of its behaviour, and its very high association with HLA A29 together suggest that BSCR is a single nosological entity. There is no evidence of a single cause, and it is possible that the disorder represents a specific response to a variety of pathogenetic agents.

We thank Mr R Blach and Professor A Bird for their valuable criticism and help in reading the manuscript. We also thank Mrs $G$ Coulier and Mrs I Jeltes for their secretarial assistance.

\section{References}

1 Ryan SJ, Maumenee AE. Birdshot retinochoroidopathy. Am J Ophthalmol 1980; 89: 31-45.

2 Gass JDM. Vitiliginous chorioretinitis. Arch Ophthalmol 1981; 99: 1778-87.

3 Aaberg TM. Diffuse inflammatory salmon patch choroidopathy syndrome. Read before the International Fluorescein Macula Symposium, Carmel, California, October 1979.

4 Amalric $P$, Cuq $G$. Une forme très particulière de choriorétinopathie en grains de riz. Bull Soc Ophtalmol Fr 1981; 81: 131-4.

5 Franceschetti A, Babel J. La choriorétinite en taches de bougie, manifestation de la maladie de Besnier-Boeck. Ophthalmologica 1949; 118: 701-10.

6 Kaplan HJ, Aaberg RM. Birdshot retinochoroidopathy. Am J Ophthalmol 1980; 90: 773-82. 
7 Nussenblatt RB, Mittal KK, Ryan SJ, Green WR, Maumenee AE. Birdshot retinochoroidopathy associated with HLA-A29 antigen and immune responsiveness to retinal S-antigen. Am J Ophthalmol 1982; 94: 147-58.

8 Soubrane G, Coscas G, Binaghi M, Amalric P, Bernard JA. Birdshot retinochoroidopathy and subretinal new vessels. $\mathrm{Br} \mathrm{J}$ Ophthalmol 1983; 67: 461-74.

9 Brucker AJ, Deglin EA, Bene C, Hoffman ME. Subretinal choroidal neovascularization in birdshot retinochoroidopathy. Am J Ophthalmol 1985; 90: 40-4.

10 Laroche L, Saraux H, Quentel G, Le Hoang P. Birdshot chorioretinopathy après décollement de rétine: origine autoimmune probabl. Bull Soc Ophtalmol Fr 1983; 83: 1245-7.

11 Fuerst DJ, Tessler HH, Fishman GA, Yokoyama MM, Wykinny GJ, Vygantas CM. Birdshot retinochoroidopathy. Arch Ophthalmol 1984; 102: 214-9.

12 De Laey JJ, Priem HA. Birdshot chorioretinopathy: an etiological problem. Bull Soc Belge Ophtalmol 1981; 193: 131-6.

13 Oosterhuis JA, Baarsma GS, Polak BCP. Birdshot chorioretinopathy-vitiliginous chorioretinitis. Int Ophthalmol 1982; 5: 137-44.
14 Salvanet-Bouccara A, Forrestier F. Choriorétinopathie de type birdshot. J Fr Ophthalmol 1983; 6: 671-6.

15 Rosenberg PR, Noble KG, Walsh JB, Carr RE. Birdshot retinochoroidopathy. Ophthalmology 1984; 91: 304-6.

16 Katsnelson LA, Kaliberdina AF. Birdshot chorioretinopathy, a new clinical syndrome. Vestn Oftalmol 1984; 5: 49-51.

17 Werner $\mathbf{H}$. Gegen ärztliche Resignation im Umgang mit der Uveitis. Klin Monatsbl Augenheilkd 1986; 188: 376-81.

18 Wagoner MD, Albert DM, Lerner AB, Kirkwood J, Forget FM, Nordlund JJ. New observations on vitiligo and ocular disease. Am J Ophthalmol 1983; 96: 16-26.

19 Yoshioka T, Yoshioka H, Tanaka F. Birdshot retinochoroidopathy as a new ocular sign of the sarcoidosis. Nippon Ganka Gakkai Zasshi 1983; 87: 283-8.

20 Brockhurst RJ, Schepens I. Uveitis: IV. Peripheral uveitis. The complication of retinal detachment. Arch Ophthalmol 1968; 80: 747-53.

21 Felder KS, Brockhurst RJ. Neovascular fundus abnormalities in peripheral uveitis. Arch Ophthalmol 1982; 110: 750-4.

22 Henkind P. Ocular neovascularisation. The Krill memorial lecture. Am J Ophthalmol 1978; 85: 287-301. 